\title{
PENGARUH PEMBERIAN BERBAGAI KADAR GETAH BUAH PEPAYA (Carica papaya, L.) TERHADAP JUMLAH KUMULATIF KEMATIAN LARVA Aedes aegypti
}

\author{
Rina Widiastuti, Ismiyati, Resmi Aini \\ Poltekkes Bhakti Setya Indonesia, Yogyakarta \\ Email: shesmiya@gmail.com
}

\begin{abstract}
Background: Papaya is a kind of plats which has the medicinal effect. Papaya's sap (latex) contains papain, cimopapain and lysozim as protein destructor enzyme. Satrija guess that these enzymes has an anthelmintical activity. The research aim was to know the influence of papaya's sap (latex) as a larvacide in several kind of doses (concentration).

Methods: This research was true experimental design with posttest only control group design. Papaya's sap was made as powder, afterward it was used for the research to know influence of Papaya's sap in several kinds of doses (consentration) related to larval cumulative mortality rate of Aedes aegypti. Larvicidal activity was calculated based on larval mortality after 24 hours of exposure that was taken notes for each treated group. Data processing used SPSS program version 11,0 with significance 95\% that contains data normality test, varians homogeneity test, One Way Anova, and Scheffe Post Hoc Test to know difference in larval cumulative mortality rate.

Results: The result from Anova test shown a significant result in cause larval cumulative mortality rate of Aedes aegypti ( $p$-value $<0.05$ ) in comparison with negative gontrol group. Treated group with Papaya's sap 1\% shown higest larvacidal activity.

Conclusion: Papaya's sap has larvacidal activity at the concentration of $0,16 \% ; 0,3 \% ; 0,5 \%$; and $1 \%$. At concentration of 1\%, papaya's sap shown higest larvacidal activity and shown a significant result.
\end{abstract}

Keywords: papaya, larvacide, larvae of Aedes aegypti

\begin{abstract}
Abstrak
Latar belakang: Pepaya (Carica papaya L.) adalah jenis tumbuhan yang memiliki khasiat sebagai obat. Getah buah pepaya mengandung papain, cimopapain dan lysozim sebagai enzim perusak protein. Satrija menduga bahwa enzim ini memiliki aktivitas anthelmintika. Tujuan penelitian ini adalah mencari data empiris getah buah pepaya (Carica papaya, L.) sebagai larvasida.

Metode: Penelitian ini merupakan penelitian eksperimental dengan desain posttest only control group design. Penelitian ini menggunakan getah buah pepaya (Carica papaya L.) yang dibuat serbuk untuk mengetahui pengaruh getah pepaya pada berbagai konsentrasi yang berkaitan dengan angka kematian kumulatif larva nyamuk Aedes aegypti. Aktivitas larvasida dihitung berdasarkan angka kematian larva setelah 24 jam paparan pada setiap kelompok perlakukan. Pengolahan data menggunakan program SPSS versi 11,0 dengan signifikansi $95 \%$ yang berisi uji normalitas data, uji homogenitas varian, One Way Anova, dan Scheffe Post Hoc Test untuk mengetahui perbedaan tingkat kematian kumulatif larva.

Hasil: Hasil uji Anova menunjukkan hasil yang signifikan dalam menyebabkan tingkat kematian kumulatif larva Aedes aegypti $(p$-value $<0,05)$ dibandingkan dengan kelompok kontrol negatif. Kelompok perlakuan getah buah papaya konsentrasi $1 \%$ menunjukkan aktivitas larvasida yang tertinggi.

Kesimpulan: Getah buah pepaya pada konsentrasi 0,16\%; 0,3\%; 0,5\%; dan 1\% memiliki aktivitas larvasida. Pada konsentrasi $1 \%$, getah buah pepaya yang menunjukkan aktivitas larvasida yang tertinggi dan menunjukkan hasil yang signifikan.
\end{abstract}

Kata Kunci: pepaya, larvasida, larva Aedes aegypti 


\section{Pendahuluan}

Penyakit demam berdarah dengue (DBD) merupakan penyakit virologis berbahaya karena dapat menimbulkan pendarahan dan shock yang dapat menyebabkan kematian pada penderitanya. Selama tahun 1996-2005 tercatat 334.685 kasus DBD dengan jumlah penderita yang meninggal 3.092 orang. Jumlah kasus DBD menunjukkan kecenderungan meningkat setiap tahun, demikian pula luas wilayah yang terjangkit. Departemen kesehatan telah mengupayakan berbagai cara untuk mengatasi kasus ini. Upaya pencegahan DBD secara fisis dan kimiawi kurang berhasil, dan upaya pengobatan secara formal masih terbatas. ${ }^{1}$ Pengurangan populasi nyamuk tanpa membasmi jentik nyamuk tidak banyak berarti karena dalam waktu lama jentik akan tumbuh menjadi nyamuk dewasa dan siap menularkan penyakit lagi. Pengendalian larva/jentiknya dilakukan dengan penaburan bubuk temephos pada tempat-tempat penampungan air. Cara ini sangat efektif untuk membunuh jentik atau larva nyamuk demam berdarah namun cara ini relatif mahal. ${ }^{2}$

Berdasarkan hasil penelitian untuk menentukan status resistensi nyamuk Aedes aegypti terhadap larvasida temephos (1 SG), diketahui bahwa nyamuk $A$. aegypti di beberapa wilayah pengujian di Indonesia telah resisten terhadap temephos. ${ }^{3}$ Untuk itu perlu dikembangkan larvasida alternativ dari bahan alam/nabati untuk pencegahan demam berdarah.

Tanaman pepaya (Carica papaya, L.) merupakan salah satu tanaman yang telah diketahui khasiatnya dalam pengobatan. Batang, daun, dan buah pepaya mengandung getah yang berwarna putih yang mengandung enzim pemecah protein/proteolitik yaitu enzim papain, kimopapain,dan lisozim. Papain dari batang dan daun hanya memiliki aktivitas proteolitik sekitar $200 \mathrm{MCU} / g$ ram sementara dari buahnya jauh lebih banyak, seriar $400 \mathrm{MCU} / \mathrm{gram} .{ }^{4}$

Ada beberapa keuntungan dalam penggunaan enzim papain ini, yakni tidak bersifat toksik, tak ada reaksi samping, tak ada mengubah tekanan, suhu dan $\mathrm{pH}$ yang drastis, dan pada konsentrasi rendah sudah bisa berfungsi baik. ${ }^{4}$ Menurut Satrija, getah pepaya memiliki aktivitas obat cacing (anthelmintika) dengan efikasi tinggi, dan diduga zat yang mempunyai aktivitas kuat sebagai antelmintika dari getah pepaya adalah enzim proteolitik. ${ }^{5}$ Berdasarkan penelitian, ekstrak daun pepaya juga mempunyai aktivitas larvasida. ${ }^{6}$

Dari uraian di atas, larvasida dari bahan alam dapat menjadi solusi alternatif dalam pemberantasan larva penyebab demam berdarah. Oleh karena itu, peneliti tertarik melakukan penelitian untuk mengetahui pengaruh pemberian berbagai kadar getah buah pepaya (Carica papaya, L.) terhadap jumlah kumulatif kematian larva Aedes aegypti.

\section{Metode Penelitian}

\section{A. Jenis Penelitian}

Jenis penelitian ini adalah eksperimental murni (True experiment) karena peneliti memberikan perlakuan langsung pada sampel.

\section{B. Desain Penelitian}

Desain penelitian ini adalah Postest Only Control Group Design ${ }^{7}$

\begin{tabular}{lcc} 
& Perlakuan & Postest \\
\hline Kelompok perlakuan & $\mathrm{X}$ & $\mathrm{O} 2$ \\
\hline Kelompok kontrol & & O2' \\
\hline
\end{tabular}

Keterangan :

X : Pemberian getah buah pepaya (Carica papaya L.) dengan berbagai kadar yaitu 0,16\% b/v, 0,30\% b/v, 0,5\% b/v, dan $1 \% \mathrm{~b} / \mathrm{v}$ 
O2 : Observasi hasil perhitungan terhadap jumlah kumulatif kematian larva Aedes aegypti terhadap pemberian getah buah papaya (Carica papaya L.) dengan berbagai kadar

O2' : Observasi hasil perhitungan jumlah kumulatif kematian larva Aedes aegypti pada kelompok kontrol.

\section{Metode Penelitian}

\section{1) Alat Penelitian}

Peralatan yang digunakan dalam penelitian ini adalah timbangan analitik, alat-alat pembuatan tepung getah buah pepaya, alat-alat gelas, wadah perindukan larva, alat pengering, pisau sadap.

2) Bahan Penelitian

Bahan-bahan yang digunaka dalam penelitian ini adalah, larva Aedes aegypti Instar III, getah buah pepaya (Carica papaya L.), air sumur, temephos.

\section{Langkah penelitian}

\section{1) Tahap Persiapan Penelitian}

\section{a. Penyiapan larva Aedes aegypti}

Nyamuk Aedes aegypti dewasa yang ditangkap dari alam lingkungan laboratorium Entomologi FK UGM dipindahkan ke sarang nyamuk dengan menggunakan aspirator. Untuk makanan nyamuk disediakan larutan gula $10 \%$ yang diserapkan pada kapas yang ditaruh pada cawan plastik. Untuk tempat bertelur nyamuk betina disediakan cawan plastik yang telah diisi dengan air sumur yang telah didiamkan sehari semalam. Telur diambil dan diletakkan di atas nampan plastik untuk ditetaskan. Telur yang telah menetas kemudian larvanya dipelihara, kemudian dimasukkan dalam baki perindukan berisi $1000 \mathrm{ml}$ air dan diberi makanan ikan sebagai makanannya. Ditunggu sampai berumur 3 sampai 4 hari untuk mencapai instar III. Larva instar III inilah yang digunakan sebagai sampel penelitian.

b. Penyiapan getah buah pepaya

Getah disadap dari buah pepaya yang masih muda kurang lebih berumur 2,5-3 bulan. Satu buah pepaya dapat dilakukan 5 kali penyadapan. Tiap sadapan menghasilkan kurang lebih 20 gram getah. Getah dapat diambil setiap 4 hari dengan jalan menggoreskan buah tersebut dengan pisau. ${ }^{4}$ Dari hasil penyadapan diperoleh getah basah sebanyak 15 gram.

c. Pembuatan tepung getah buah pepaya (Carica papaya L.)

Getah buah pepaya yang disadap ditampung dalam wadah. Setelah terkumpul, getah ditempatkan dalam nampan aluminium, kemudian dikeringkan dengan oven pada suhu $40-50^{\circ} \mathrm{C}$. Selama pengeringan, kebersihan getah dan lingkungan harus betul-betul dijaga. Setelah kering, kemudian ditumbuk dan disaring hingga didapat tepung halus, sehalus tepung beras atau terigu. ${ }^{8}$ Dari 15 gram getah basah diperoleh 3 gram tepung kering

d. Pembuatan larutan temephos $0,01 \% \mathrm{~b} / \mathrm{v}$

Timbang seksama 0,01 gram abate kemudian dilarutkan dalam air $100 \mathrm{ml}$.

2) Uji pengaruh pemberian berbagai kadar getah buah pepaya (Carica papaya, L.) terhadap jumlah kumulatif kematian larva Aedes aegypti Cara kerja :

a. Disiapkan larva yang akan diteliti pada media larva kemudian disiapkan 18 buah mangkok dan diberi nomor. 
b. Mangkok I diisi $95 \mathrm{ml}$ air sumur ditambah $5 \mathrm{ml}$ air media larva, kemudian diisikan 20 larva dan ditaburi 0,16 gram tepung getah pepaya (Carica papaya, L.).

c. Mangkok II diisi $95 \mathrm{ml}$ air sumur ditambah $5 \mathrm{ml}$ air media larva, kemudian diisikan 20 larva dan ditaburi 0,3 gram tepung getah pepaya (Carica papaya, L.).

d. Mangkok III diisi $95 \mathrm{ml}$ air sumur ditambah $5 \mathrm{ml}$ air media larva, kemudian diisikan 20 larva dan ditaburi 0,5 gram tepung getah pepaya (Carica papaya, L.).

e. Mangkok IV diisi $95 \mathrm{ml}$ air sumur ditambah $5 \mathrm{ml}$ air media larva, kemudian diisikan 20 larva dan ditaburi 1 gram tepung getah pepaya (Carica papaya, L.).

f. Mangkok V sebagai kontrol positif, diisi $95 \mathrm{ml}$ air sumur ditambah $5 \mathrm{ml}$ air media larva, kemudian diisikan 20 larva dan ditaburi 0,01 gram bubuk temephos.

g. Mangkok VI sebagai kelompok kontrol negatif diisi dengan $95 \mathrm{ml}$ air sumur dan ditambah air media larva $5 \mathrm{ml}$, dan diisi 20 ekor.

h. Semua mangkok dibiarkan pada suhu ruang $25^{\circ} \mathrm{C}$ dan kelembaban $70 \%$.

i. Replikasi dilakukan sebanyak 3 kali untuk setiap kelompok perlakuan. Pembacaan dilakukan setelah 24 jam dicatat jumlah larva yang mati pada setiap kelompok.

\section{E. Pengolahan dan Analisis Data}

1. Pengumpulan data

2. Koreksi data

Meneliti data yang diproleh meliputi kelengkapan data. Selanjutnya untuk memudahkan analisis data, maka data yang diperoleh ditabulasikan dalam bentuk tabel

3. Analisa data

Analisa dengan program SPSS versi 11.0 dengan taraf signifikansi $95 \%$, yang meliputi :

1. Uji Normalitas Data

2. Homogenitas varians.

3. Anava satu jalan

Uji Analisa Varian satu jalan digunakan untuk mengetahui perbedaan jumlah kumulatif kematian larva

4. Scheffe Post Hoc Test

Digunakan untuk menguji pasangan mean yang berbeda dengan taraf kepercayaan $95 \%$ pada pengujian dengan Anova satu jalan. Adapun untuk mengetahui signifikansi atau kemaknaan dapat diketahui dengan $p$-value: apabila $p$-value $<0,05$ berarti ada perbedaan yang signifikan dan jika $p$ value $>0,05$ artinya perbedaannya tidak bermakna.

\section{Hasil Penelitian dan Pembahasan}

\section{A. Hasil Pembuatan Tepung Getah Buah Pepaya (Carica papaya L.)}

Getah buah pepaya (Carica papaya L.) yang digunakan diambil dari daerah Pilahan Kotagede Yogyakarta pada bulan Juli 2009.

Getah hasil sadapan yang diperoleh adalah sebanyak 15 gram getah basah. Selanjutnya getah basah dikeringkan dengan oven pada suhu $40-50{ }^{\circ} \mathrm{C}$. Suhu yang digunakan disini tidak mempengaruhi aktivitas enzim dalam getah buah pepaya, karena enzim papain dan kimopapain mempunyai daya tahan 
panas yang baik. ${ }^{8}$ Selama pengeringan, kebersihan getah dan lingkungan harus betul-betul dijaga. Setelah kering, kemudian ditumbuk dan disaring dengan ayakan nomer 50, hingga didapat tepung halus, sehalus tepung beras atau terigu.

15 gram getah basah dapat diperoleh 3 gram tepung kering. Secara organoleptis, tepung getah pepaya yang dihasilkan mempunyai warna putih kuning kecoklatan, berbau getah pepaya, dan jika diraba terasa agak lengket ditangan. Tepung getah buah pepaya yang diperoleh ini selanjutnya digunakan untuk penelitian.

Metode pembuatan tepung ini lebih dipilih karena memiliki beberapa kelebihan yaitu sangat sederhana, mudah digunakan, tidak butuh waktu lama dalam pengerjaannya, dan tepung yang dihasilkan cukup stabil dalam penyimpanan.

\section{B. Hasil Uji Pengaruh Pemberian Berbagai Kadar Getah Buah Pepaya (Carica} papaya, L.) terhadap Jumlah Kumulatif Kematian Larva Aedes aegypti

Penelitian ini dilakukan untuk mengetahui apakah pemberian tepung getah buah pepaya (Carica papaya L.) dengan berbagai kadar mempunyai pengaruh terhadap jumlah kumulatif kematian larva Aedes aegypti.

Uji pengaruh pemberian berbagai kadar getah buah pepaya (Carica papaya L.) ini dugunakan larva nyamuk Aedes aegypti Instar III. Tahap instar III larva Aedes aegypti digunakan dalam penelitian atas pertimbangan pada tahap instar III alat - alat tubuh nyamuk telah lengkap (bulu-bulunya) dan larva bersifat relatif stabil terhadap perubahan pengaruh luar.

Metode yang digunakan adalah dengan menebarkan tepung getah buah pepaya (Carica papaya L.) dalam mangkok media yang berisi larva nyamuk, kemudian diamati efeknya. Pada kelompok kontrol positif diberikan temephos $0,01 \%$, yang mana temephos merupakan larvasida yang telah terbukti kemampuannya membunuh larva nyamuk. Kadar temephos 0,01\% dipilih karena merupakan kadar yang efektif untuk larvasida. Pengamatan dan pengumpulan data jumlah kematian larva dilakukan setiap jam selama 24 jam, dengan jumlah tiap kelompok perlakuan adalah 20. Hasil uji statistik deskriptif pengaruh pemberian berbagai kadar getah buah pepaya (Carica papaya L.) terhadap jumlah kumulatif kematian larva Aedes aegypti dapat dilihat pada Tabel 1.

Tabel 1. Hasil uji statistik deskriptif pengaruh pemberian berbagai kadar getah buah pepaya (Carica papaya L.) terhadap jumlah kumulatif kematian larva Aedes aegypti

\begin{tabular}{|c|c|c|c|c|c|c|c|c|c|c|c|c|c|c|c|c|c|}
\hline \multicolumn{12}{|c|}{$\begin{array}{l}\text { Jumlah kumulatif kematian larva pada kadar getah buah pepaya } \\
\qquad \text { (Carica papaya L.) pada dosis }\end{array}$} & \multirow{2}{*}{\multicolumn{3}{|c|}{$\begin{array}{c}\text { temephos } \\
0,01 \%\end{array}$}} & \multirow{2}{*}{\multicolumn{3}{|c|}{ Kontrol negatif }} \\
\hline \multicolumn{3}{|c|}{$0,16 \%$} & \multicolumn{3}{|c|}{$0,30 \%$} & \multicolumn{3}{|c|}{$0,50 \%$} & \multicolumn{3}{|c|}{$1 \%$} & & & & & & \\
\hline 1 & 2 & 3 & 1 & 2 & 3 & 1 & 2 & 3 & 1 & 2 & 3 & 1 & 2 & 3 & 1 & 2 & 3 \\
\hline 15 & 16 & 17 & 18 & 17 & 18 & 14 & 17 & 16 & 20 & 20 & 20 & 20 & 20 & 20 & 0 & 0 & 0 \\
\hline \multicolumn{3}{|c|}{$\begin{array}{l}\text { Rata-rata }=16 \\
\text { ekor }\end{array}$} & \multicolumn{3}{|c|}{$\begin{array}{l}\text { Rata-rata }=18 \\
\text { ekor }\end{array}$} & \multicolumn{3}{|c|}{$\begin{array}{l}\text { Rata-rata }=16 \\
\text { ekor }\end{array}$} & \multicolumn{3}{|c|}{$\begin{array}{l}\text { Rata-rata }=20 \\
\text { ekor }\end{array}$} & \multicolumn{3}{|c|}{$\begin{array}{l}\text { Rata-rata }=20 \\
\text { ekor }\end{array}$} & \multicolumn{3}{|c|}{$\begin{array}{l}\text { Rata-rata }=0 \\
\text { ekor }\end{array}$} \\
\hline \multicolumn{3}{|c|}{$\begin{array}{l}\text { Persentase = } \\
\quad 80 \%\end{array}$} & \multicolumn{3}{|c|}{$\begin{array}{l}\text { Persentase = } \\
\quad 90 \%\end{array}$} & \multicolumn{3}{|c|}{$\begin{array}{l}\text { Persentase = } \\
\quad 80 \%\end{array}$} & \multicolumn{3}{|c|}{$\begin{array}{l}\text { Persentase = } \\
100 \%\end{array}$} & \multicolumn{3}{|c|}{$\begin{array}{l}\text { Persentase = } \\
100 \%\end{array}$} & \multicolumn{3}{|c|}{$\begin{array}{l}\text { Persentase = } \\
0 \%\end{array}$} \\
\hline
\end{tabular}

Persentase didapat dari data rata-rata jumlah kumulatif kematian larva pada setiap kelompok perlakuan dibagi 20 , kemudian dikalikan $100 \%$. 
Berdasarkan uji normalitas populasi dengan metode KolmogorovSmirnov dapat dilihat bahwa data pada sampel pada setiap kelompok perlakuan terambil dari populasi yang berdistribusi normal dengan $p$-value $>0,05$.

Hasil uji homogenitas varian menunjukkan bahwa syarat homogenitas varian diterima dengan $p$-value $>0,05$. Hal ini menunjukkan bahwa variansi data pada semua kelompok perlakuan adalah sama.

Hasil uji statistik jumlah kumulatif kematian larva pada keenam kelompok perlakuan (kelompok I, II, III, IV, V, VI) menunjukkan Ho mengenai kelompok perlakuan ditolak pada $\alpha=0,05$ ( sebab $p$-value $=0,000<0,05=\alpha$ ). Hal ini menunjukkan ada perbedaan bermakna dalam menimbulkan jumlah kumulatif kematian antara keenam kelompok perlakuan tersebut.

Hasil uji post hoc dengan metode Scheffe pada kelompok perlakuan dapat dilihat pada Tabel 2.

Tabel 2. Hasil uji post hoc dengan metode Scheffe pada kelompok perlakuan dengan berbagai kadar getah buah pepaya (Carica papaya L.) terhadap jumlah kumulatif kematian larva Aedes aegypti

\begin{tabular}{|c|c|c|}
\hline Perbedaan antar kelompok & Nilai signifikansi & Kebermaknaan hasil uji \\
\hline Kadar $0,16 \%$ dengan kadar $0,3 \%$ & 0,304 & Berbeda tidak bermakna \\
\hline Kadar $0,16 \%$ dengan kadar $0,5 \%$ & 0,998 & Berbeda tidak bermakna \\
\hline Kadar $0,16 \%$ dengan kadar $1 \%$ & 0,638 & Berbeda tidak bermakna \\
\hline Kadar 0,3 \% dengan kadar 0,5\% & 0,157 & Berbeda tidak bermakna \\
\hline Kadar 0,3 \% dengan kadar $1 \%$ & 0,076 & Berbedatidak bermakna \\
\hline Kadar $0,5 \%$ dengan kadar $1 \%$ & 0,001 & Berbeda bermakna \\
\hline Kontrol (+) dengan Kadar 0,16\% & 0,002 & Berbeda bermakna \\
\hline Kontrol (+) dengan Kadar 0,3\% & 0,076 & Berbeda tidak bermakna \\
\hline Kontrol $(+)$ dengan kadar $0,5 \%$ & 0,001 & Berbeda bermakna \\
\hline Kontrol (+) dengan Kadar $1 \%$ & 1,000 & Berbeda tidak bermakna \\
\hline Kontrol (--) dengan Kadar 0,16\% & 0,000 & Berbeda bermakna \\
\hline Kontrol (--) dengan Kadar 0,3\% & 0,000 & Berbeda bermakna \\
\hline Kontrol (--) dengan Kadar 0,5\% & 0,000 & Berbeda bermakna \\
\hline Kontrol (--) dengan Kadar 1 \% & 0,000 & Berbeda bermakna \\
\hline Kontrol (--) dengan Kontrol (+) & 0,000 & Berbeda bermakna \\
\hline
\end{tabular}

Hasil penelitian ini menunjukkan getah buah pepaya (Carica papaya L.) mempunyai khasiat larvasida, hal ini dapat dilihat dari hasil uji statistik bahwa semua kelompok perlakuan yang diberi getah buah pepaya (Carica papaya L.) menunjukkan hasil berbeda bermakna terhadap kelompok kontrol negatif yang tidak diberi getah buah pepaya. Kelompok perlakuan dengan getah buah pepaya (Carica papaya L.) mempunyai kemampuan larvasida lebih rendah daripada kelompok yang diberi abate $0,01 \%$. Hal ini ditunjukkan oleh waktu kematian $100 \%$ sampel larva penelitian, yang mana pada kelompok perlakuan dengan temephos 0,01\% menunjukkan waktu kematian 100\% larva pada jam pertama pengamatan, sedangkan pada kelompok perlakuan dengan getah buah pepaya (Carica papaya L.) pada berbagai kadar $100 \%$ jumlah kematian larva belum tercapai pada 24 jam kematian. Diantara kelompok perlakuan dengan getah buah pepaya (Carica papaya L.), kelompok perlakuan getah pepaya (Carica papaya L.) kadar $1 \%$ mampunyai kemampuan larvasida yang paling besar dan menunjukkan hasil perbedaan bermakna. Dapat dilihat bahwa ada kecenderungan dengan meningkatnya kadar getah buah pepaya (Carica papaya L.) yang digunakan meningkat pula jumlah kumulatif kematian larva.

Getah buah pepaya (Carica papaya L.), seperti pada antelmintik, papain bekerja seperti melunakkan daging. Papain melemaskan cacing dengan cara merusak protein tubuh cacing. Sehingga sangat dimungkinkan papain juga 
mampu merusak protein tubuh larva sehingga dapat melemaskan dan akhirnya mematikan larva.

\section{Simpulan dan Saran}

\section{A. Simpulan}

Semua kelompok perlakuan yang diberi getah buah pepaya (Carica papaya L.) menunjukkan hasil berbeda bemakna dalam menyebabkan jumlah kumulatif kematian larva Aedes aegypti $(p$ value $<0,05)$ terhadap kelompok kontrol negatif yang tidak diberi getah buah pepaya. Kelompok perlakuan getah pepaya (Carica papaya L.) kadar $1 \%$ mempunyai kemampuan larvasida yang paling besar.

\section{B. Saran}

Saran dari penelitian ini adalah:

1) Perlu dilakukan penelitian pengaruh berbagai kadar getah buah papaya terhadap jumlah kumulatif kematian larva, dengan menggunakan kadar getah buah pepaya yang berbeda dan metode pembuatan tepung getah papaya yang berbeda juga.

2) Perlu dilakukan pengujian komponen senyawa aktif terhadap tepung gatah buah pepaya yang digunakan dalam penelitian ini

3) Perlu penelitian lebih lanjut tentang mekanisme efek larvasida dari getah buah papaya.

\section{Daftar Pustaka}

1. Barmawie, N., Mengatasi Demam Berdarah dengan Tanaman Obat, Warta Penelitian dan Pengembangan Pertanian, vol/no: 28(6), Balittro, Bogor, 2006.

2. Hasyimi, M., Aedes aegypti sebagai Vektor Demam Berdarah Dengue Berdasarkan Pengamatan di Alam, Media Litbangkes, vol/no: 3(5), 1993.

3. Raharjo, B., Uji Kerentanan (Susceptibility Test) Nyamuk aedes aegypti (Linnaeus) dari Surabaya, Palembang, dan Beberapa Wilayah di Bandung terhadap Temephos (Abate 1 SG), Tugas Akhir, Institut Teknologi Bandung, Bandung, 2006.

4. htpp://www.Kompas.com Ristek.go.id.

5. htpp://www.smallstock.Info/reference/KVLDK/Satrija, 2005.

6. Aini R., Pengaruh Ekstrak Daun Pepaya (Carica papaya, L.) Terhadap Pertumbuhan Larva Aedes aegypti, Laporan Penelitian, Program Sumber Daya Kesehatan Propinsi DIY, Yogyakarta, 2006.

7. Nazir, M., Metodologi Penelitian, Cetakan ke-3, Ghalia Indonesia, Jakarta, 1988.

8. Koswara, S., htpp://www.Ebookpangan.com.(PDF)HTML. 
